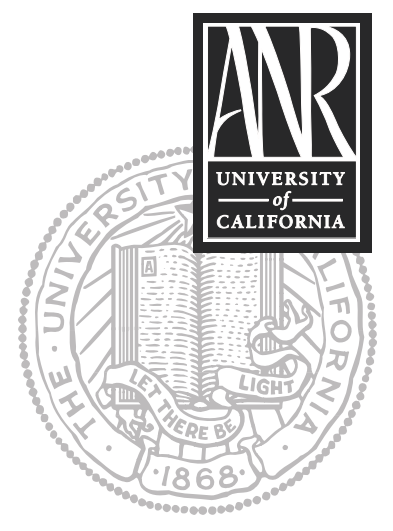

UNIVERSITY OF CALIFORNIA

Division of Agriculture and Natural Resources http://anrcatalog.ucdavis.edu

\title{
NUTRITION AND HEALTH INFO SHEET Cholesterol
}

NADINE J. KIRKPATRICK, Department of Nutrition, University of California, Davis; CRISTY HATHAWAY, Research Assistant, Department of Nutrition, University of California, Davis; KARRIE HENEMAN, Assistant Project Scientist, Department of Nutrition, University of California, Davis; SHERI ZIDENBERG-CHERR, UC Cooperative Extension Nutrition Science Specialist, Department of Nutrition, University of California, Davis

\section{SOME FACTS ABOUT CHOLESTEROL}

More than 102 million Americans have high cholesterol, defined as above $200 \mathrm{mg} / \mathrm{dl}$ (milligrams per deciliter). A great portion of this group has cholesterol values that pose a high risk for developing atherosclerosis, which can lead to coronary heart disease. ${ }^{1}$

\section{What is cholesterol?}

Cholesterol is a fatty substance (lipid) that has a waxy appearance and is found in the body cells of humans and animals, particularly the brain, kidneys, and liver. High amounts of cholesterol in our diets and blood can be viewed negatively because it is associated with coronary heart disease. ${ }^{1}$ However, it is important to recognize that our bodies need cholesterol in many different ways.

\section{How does the body use cholesterol?}

The body uses cholesterol in the following ways:

- to form hormones such as estrogen and testosterone

- to keep the structure of cells in the body intact

- to make the active form of vitamin D

- to make bile acids which are compounds necessary for fat digestion ${ }^{2}$

\section{What are the two sources of cholesterol?}

Diet

Dietary cholesterol comes only from animal sources, such as dairy products, egg yolks, meats, poultry, and seafood. No vegetables, fruits, or grains contain cholesterol. ${ }^{1}$ Baked products may contain some cholesterol if they contain egg yolks, cheese, milk, butter, or lard. In milk products the majority of the cholesterol is in the fat, so low-fat or skim milk contains less cholesterol than whole-milk products. ${ }^{2}$

\section{Body}

No dietary requirement exists for cholesterol because the body can make enough cholesterol to meet its needs. ${ }^{1}$ The body can make cholesterol from compounds produced by the breakdown of protein, carbohydrates, or fats. ${ }^{3}$ The liver is the organ responsible for about 10 percent of cholesterol synthesis, and its function has a significant impact on blood cholesterol levels. However, some people lack the ability to control the amount of cholesterol they make and as a result they are prone to high levels of cholesterol in their blood stream. ${ }^{2}$

\section{What are the different types of cholesterol found in the body?}

Cholesterol, triglycerides (TG), and other fats travel through the bloodstream packaged with large molecules called lipoproteins. These packages differ from one another 
carried in the blood by two different types of lipoproteins: high-density lipoprotein (HDL) and low-density lipoprotein (LDL).

Three main lipoproteins exist in our blood:

\section{High-density lipoprotein}

HDL is also known as the "good" cholesterol since it is believed to carry cholesterol out of the blood vessels to the liver, where it is removed from the body.

\section{Low-density lipoprotein}

This is the largest portion of blood cholesterol. ${ }^{4}$ Because this form of cholesterol may contribute to the formation of plaque in blood vessels, LDL is often referred to as the "bad" cholesterol.

\section{Very low-density lipoprotein (VLDL)}

VLDL is very high in triglycerides and does not carry cholesterol in the blood.

\section{What are the guidelines for cholesterol levels?}

For adults, total blood cholesterol below $200 \mathrm{mg} / \mathrm{dl}$ is desirable, because these levels are associated with a relatively low risk of coronary heart disease. Levels in the range of 200-239 mg/dl are considered "borderline," and total cholesterol levels above 240 $\mathrm{mg} / \mathrm{dl}$ are associated with high risk and the need for treatment. Coronary heart disease (CHD) risk is much greater at serum lipid levels above $200-239 \mathrm{mg} / \mathrm{dl}$ due to elevations in LDL-cholesterol. In several studies, high HDL values (above $60 \mathrm{mg} / \mathrm{dl}$ ) actually seem to be protective and have been associated with a lower incidence of heart disease. ${ }^{4}$ (See the metric conversion table at the end of this publication.)

\begin{tabular}{|c|c|c|c|}
\hline & $\begin{array}{l}\text { Desirable } \\
\text { (mg/dl) }\end{array}$ & $\begin{array}{l}\text { Borderline } \\
\text { (mg/dl) }\end{array}$ & $\begin{array}{c}\text { High risk } \\
\text { (mg/dl) }\end{array}$ \\
\hline Total cholesterol & $<200$ & $200-239$ & $>240$ \\
\hline LDL-cholesterol & $<130$, but $<100$ optimal & 130-159 & $>160$ \\
\hline HDL-cholesterol & $>60$, but $40-59$ normal range & $\begin{array}{l}<40 \text { for men } \\
<50 \text { for women }\end{array}$ & $<35$ \\
\hline TG & $<150$ & 150-199 & $>200$ \\
\hline
\end{tabular}

\section{How can total cholesterol and LDL-cholesterol levels be reduced?}

The American Heart Association recommends that dietary cholesterol be controlled by

- limiting total cholesterol to an average of $300 \mathrm{mg}$ or less per day

- limiting total fat to no more than 30 percent and saturated fat to no more than 10 percent of total calorie intake

- eating 5 to 9 servings of vegetables, fruits, and grain products, which have been shown to lower serum cholesterol levels ${ }^{1}$

A physician should be consulted in order to treat each individual in regard to cholesterol levels. It is recommended that blood cholesterol levels be tested every 5 years after the age of 20. If blood cholesterol is found to be high, dietary measures can be taken to try to reduce the levels. If after several months dietary modifications have minimal impact on the serum cholesterol levels, a physician may prescribe a cholesterol-lowering drug, particularly if there are other risk factors or symptoms of CHD. 


\section{How can HDL-cholesterol be increased?}

Excess body weight and cigarette smoking are associated with low HDL-cholesterol levels. Exercise can help raise HDL-cholesterol. The exercise doesn't have to be strenuous; just walking a mile or two or even gardening several times a week can help. ${ }^{1}$ Since the dietary intake of fat, saturated fat, and cholesterol can influence the risk of cardiovascular disease, the table below includes values for each of these categories. ${ }^{1,5}$

\section{How can cholesterol levels be reduced?}

The following list offers dietary suggestions for reducing cholesterol:

- Eat 5 to 9 servings of vegetables and fruits, and 6 to 11 servings of grain products. ${ }^{1}$

What is the cholesterol, total fat, and saturated fat content of some common foods?

\begin{tabular}{|c|c|c|c|}
\hline & $\begin{array}{l}\text { Cholesterol } \\
\text { (mg) }\end{array}$ & $\begin{array}{l}\text { Total fat } \\
\text { (g) }\end{array}$ & $\begin{array}{c}\text { Saturated } \\
\text { fat } \\
\text { (g) }\end{array}$ \\
\hline \multicolumn{4}{|l|}{ Dairy products } \\
\hline \multicolumn{4}{|l|}{ milk, 1 cup } \\
\hline $3.25 \%$ fat & 34.2 & 8.2 & 5.0 \\
\hline $2 \%$ fat & 19.5 & 4.7 & 2.9 \\
\hline $1 \%$ fat & 9.8 & 2.6 & 1.6 \\
\hline skim (nonfat) & 4.9 & 0.4 & 0.3 \\
\hline \multicolumn{4}{|l|}{ yogurt, 1 cup } \\
\hline nonfat plain & 4.9 & 0.4 & 0.3 \\
\hline low-fat, plain & 14.7 & 3.8 & 2.5 \\
\hline low-fat, fruit flavored & 12.3 & 2.8 & 1.9 \\
\hline \multicolumn{4}{|l|}{ Fats, oils, sweets } \\
\hline butter, 1 tbsp & 31.1 & 11.5 & 7.2 \\
\hline cheesecake (9 in), no bake $1 / 12(99 \mathrm{~g})$ & 28.7 & 12.6 & 6.6 \\
\hline cream cheese, 1 tbsp & 16.0 & 5.1 & 3.2 \\
\hline margarine, 1 tsp & 0.0 & 3.8 & 0.7 \\
\hline mayonnaise (regular), 1 tbsp & 8.1 & 11.0 & 1.6 \\
\hline sour cream, 1 tbsp & 5.3 & 2.5 & 1.6 \\
\hline \multicolumn{4}{|l|}{ Meat, poultry, fish, and eggs } \\
\hline beef liver, braised, $3 \mathrm{oz}$ & 330.7 & 4.2 & 1.6 \\
\hline \multicolumn{4}{|l|}{ chicken, light and dark meat, roasted } \\
\hline with skin (178g) & 156.6 & 24.2 & 6.7 \\
\hline without skin (146g) & 129.9 & 10.8 & 3.0 \\
\hline lean only & 58.7 & 4.2 & 1.5 \\
\hline \multicolumn{4}{|l|}{ eggs, large, cooked, 1} \\
\hline yolk & 212.0 & 5.3 & 1.6 \\
\hline white & 0.0 & 0.0 & 0.0 \\
\hline \multicolumn{4}{|l|}{ ground beef, cooked, 3 oz patty } \\
\hline regular ( $75 \%$ lean \& $25 \%$ fat) & 76.7 & 15.9 & 6.1 \\
\hline extra lean ( $95 \%$ lean \& $5 \%$ fat) & 64.6 & 5.6 & 2.4 \\
\hline prime rib, 3 oz & 72.3 & 28.2 & 11.7 \\
\hline \multicolumn{4}{|l|}{ shrimp, steamed } \\
\hline 4 large & 42.9 & 0.2 & 0.1 \\
\hline \multicolumn{4}{|l|}{ tuna, canned, 3 oz } \\
\hline in oil & 26.4 & 6.9 & 1.4 \\
\hline in water & 35.7 & 2.5 & 0.7 \\
\hline
\end{tabular}

- Use lemon juice, salsa, or small amounts of salad dressing on salads. ${ }^{2}$

- Use moderate amounts of spreads such as butter, margarine, and mayonnaise or oils when cooking. ${ }^{2}$

- Regularly check labels on foods to see how much fat and saturated fat are being consumed. ${ }^{2}$

- Trim fat from meat; take skin off poultry. ${ }^{2}$

- Occasionally, eat cooked dry beans and peas or other vegetarian dishes instead of meat. ${ }^{2}$

- Limit the use of egg yolks and organ meats, since they are very high in cholesterol. ${ }^{2}$

- Choose skim or low-fat milk and fat-free or lowfat yogurt and cheese. ${ }^{2}$

- Steam, boil, or bake vegetables. ${ }^{2}$

- Vegetables can be seasoned with herbs and spices, which contain no calories, instead of using sauces, butter, or margarine. ${ }^{2}$

- Substitute plain low-fat yogurt for sour cream. ${ }^{2}$

\section{REFERENCES}

1. American Heart Association. 2002. American Heart Association Web site, http://www. americanheart.org/presenter.jhtml?identifier= 1200000.

2. Wardlaw, G. M. 2003. Contemporary nutrition: Issues and insights. New York: McGraw-Hill.

3. Shils, M. E. 1999. Modern nutrition in health and disease. 9th ed. Baltimore: Williams \& Wilkins.

4. Mahan, L. K., and S. Escott-Stump. 2000. Krause's food, nutrition, and diet therapy. 10th ed. Philadelphia: W. B. Saunders.

5. USDA (United States Department of Agriculture). 2002. USDA Nutrient Data Laboratory Web site, www.nal.usda.gov/fnic/cgi-bin/nut_search.pl. 
Metric Conversions

\begin{tabular}{|l|c|c|c|}
\hline English & $\begin{array}{c}\text { Conversion factor for } \\
\text { English to Metric }\end{array}$ & $\begin{array}{c}\text { Conversion factor for } \\
\text { Metric to English }\end{array}$ & Metric \\
\hline grain & 64.80 & 0.015 & milligram (mg) \\
\hline fluid ounce (fl oz) & 29.57 & 0.034 & milliliter (ml) \\
\hline fluid ounce (fl oz) & 2.96 & 0.0034 & deciliter (d) \\
\hline ounce (oz) & 28.35 & 0.035 & gram (g) \\
\hline
\end{tabular}

\section{FOR FURTHER INFORMATION}

To order or obtain ANR publications and other products, visit the ANR

Communication Services online catalog at http://anrcatalog.ucdavis.edu. You can also place orders by mail, phone, or FAX, or request a printed catalog of our products from

University of California

Agriculture and Natural Resources

Communication Services

6701 San Pablo Avenue, 2nd Floor

Oakland, California 94608-1239

Telephone: (800) 994-8849 or (510) 642-2431

FAX: (510) 643-5470

E-mail inquiries: danrcs@ucdavis.edu

An electronic version of this publication is available on the ANR Communication Services Web site at http://anrcatalog.ucdavis.edu.

This publication has been anonymously peer reviewed for technical accuracy by University of California scientists and other qualified professionals. This review process was managed by the ANR Associate Editor for Food and Nutrition.

Publication 8142

ISBN-13: 978-1-60107-499-7

(C) 2007 The Regents of the University of California

Division of Agriculture and Natural Resources

All rights reserved.

No part of this publication may be reproduced, stored in a retrieval system, or transmitted, in any form or by any means, electronic, mechanical, photocopying, recording, or otherwise, without the written permission of the publisher and the authors.

The University of California prohibits discrimination or harassment of any person on the basis of race, color, national origin, religion, sex, gender identity, pregnancy (including childbirth, and medical conditions related to pregnancy or childbirth), physical or mental disability, medical condition (cancer-related or genetic characteristics), ancestry, marital status, age, sexual orientation, citizenship, or status as a covered veteran (covered veterans are special disabled veterans, recently separated veterans, Vietnam era veterans, or any other veterans who served on active duty during a war or in a campaign or expedition for which a campaign badge has been authorized) in any of its programs or activities. University policy is intended to be consistent with the provisions of applicable State and Federal laws.

Inquiries regarding the University's nondiscrimination policies may be directed to the Affirmative Action/Staff Personnel Services Director, University of California, Agriculture and Natural Resources, 1111 Franklin Street, 6 ${ }^{\text {th }}$ Floor, Oakland, CA 94607-5201, (510) 987-0096. For information about ordering this publication, telephone 1-800-994-8849.

pr-8/07-LR/CM 